\title{
ANALISIS RISIKO RANTAI PASOK PESTISIDA PADA PT. AGRICON
}

\section{RISK ANALYSIS OF PESTICIDES SUPPLY CHAIN AT AGRICON CO.}

\author{
Fany Annisa Agusti' ${ }^{1)}$, Marimin $^{2}$, dan Heti Mulyati ${ }^{3)}$ \\ ${ }^{1)}$ Inspektorat Jenderal, Kementerian Pertanian \\ Gedung B Lantai 3, Jl. Harsono RM No. 3, Ragunan, Jakarta Selatan \\ 2)Program Studi Teknologi Industri Pertanian, Fakultas Teknologi Pertanian, IPB \\ ${ }^{3)}$ Fakultas Ekonomi Menajemen, IPB \\ Makalah: Diterima 19 Juni 2019; Diperbaiki 20 Maret 2020; Disetujui 15 April 2020
}

\begin{abstract}
One solution to increase agricultural production is to overcome pests and diseases by using pesticides, which has an influence on pesticides' availability. Therefore, it is necessary to analyse the performance and risks that arise in the pesticide supply chain. This study aimed to identify and analyse supply chain mechanisms and the performance of pesticide supply chain, and to identify and analyse risks of pesticide supply chain. The Van der Vorst method was used to analyse the structure of supply chain networks, supply chain business processes, supply chain management, and supply chain resources. The results of performance measurement using SCOR model showed that there were still around $0.61 \%$ of orders that were not fully fulfilled; the order fulfillment cycle time was 12 days; the upside supply chain flexibility matrix was three days; and the upside supply chain adaptability matrix was $11.72 \%$. Based on these results, the performance value of pesticide supply chain was $52.69 \%$ and falls into bad (unacceptable) category. These results indicate that there were still performance attributes that were not optimal. There were still lost of opportunities because the company targets were not fulfilled, which had an impact on profit loss. Risk identification using the FMEA-HOR 1 method, from 40 risk events and 24 risk agents, 10 priority of risk agents were obtained that needed to be mitigated so that the pesticides supply chain could run effectively and efficiently.
\end{abstract}

Keywords : pesticides, supply chain mechanisms, performance, risk

\section{ABSTRAK}

Salah satu solusi untuk meningkatkan produksi pertanian adalah dengan mengatasi hama dan penyakit dengan menggunakan pestisida, yang berdampak pada ketersediaan pestisida. Oleh karena itu, perlu dilakukan analisis kinerja dan risiko yang muncul dalam rantai pasok pestisida. Penelitian ini bertujuan untuk mengidentifikasi dan menganalisis mekanisme rantai pasok serta kinerja rantai pasok pestisida dan mengidentifikasi serta menganalisis risiko pada rantai pasok pestisida. Analisis mekanisme rantai pasok pestisida menggunakan metode Van der Vorst, yang digunakan untuk menganalisis struktur jaringan rantai pasok, proses bisnis rantai pasok, manajemen rantai pasok, dan sumber daya rantai pasok. Pengukuran kinerja rantai pasok pestisida dilakukan dengan metode Supply Chain Operations Reference (SCOR), yang menunjukkan masih terdapat sekitar 0,61\% pesanan yang tidak terpenuhi secara penuh; siklus pemenuhan pesanan adalah 12 hari; matrik fleksibilitas rantai pasok atas adalah 3 (tiga) hari; dan matrik penyesuaian rantai pasok atas sebesar 11,72\%. Sementara itu berdasarkan hasil perhitungan nilai kinerja rantai pasok pestisida adalah sebesar 52,69\% dan berada pada kriteria buruk (unacceptable). Hasil tersebut mengindikasikan masih adanya atribut kinerja yang dijalankan kurang optimal sehingga masih terdapat kehilangan kesempatan karena tidak terpenuhinya target perusahaan yang berdampak pada kehilangan keuntungan. Identifikasi risiko dengan metode Failure Mode Effect Analysis-House of Risk 1 (FMEA-HOR 1), dari 40 kejadian risiko dan 24 sumber risiko, diperoleh 10 prioritas sumber risiko yang perlu dikurangi sehingga rantai pasok pestisida dapat berjalan secara efektif dan efisien.

Kata kunci: pestisida, mekanisme rantai pasok, kinerja, risiko

\section{PENDAHULUAN}

Ketahanan pangan merupakan sebuah kondisi yang terkait dengan ketersediaan bahan pangan secara berkelanjutan. Berdasarkan Global Food Security Index (GFSI), posisi ketahanan pangan Indonesia mengalami kenaikan pada tahun 2017 yaitu pada posisi 69 dibandingkan pada 2016 yang berada di posisi 71. Adanya tuntutan ketahanan pangan tersebut menyebabkan perlunya program peningkatan produksi pertanian di Indonesia. Rata-rata kenaikan produksi pangan untuk padi pada 3 (tiga) tahun terakhir sebesar $2,56 \%$ dengan produksi nasional mencapai 81.382.000 ton pada tahun 2017 dan ratarata kenaikan produksi jagung sebesar 18,55\% dengan produksi nasional mencapai 27.952.000 ton, sedangkan produksi kedelai masih mengalami penurunan sebesar $36,90 \%$ dengan produksi nasional sebesar 542.000 ton (BPS, 2018). 
Berdasarkan data tersebut menunjukkan bahwa produksi pertanian di Indonesia masih rendah dan belum optimal dalam mendukung ketahanan pangan di Indonesia. Produksi pertanian yang rendah disebabkan oleh penanaman benih yang kurang bermutu dan tidak bersertifikasi, sistem budidaya tanaman yang belum optimal serta adanya serangan hama dan penyakit. Serangan hama dan penyakit pada tanaman belum dapat dikendalikan secara optimal, sehingga mengakibatkan kerugian yang cukup besar baik kehilangan hasil, menurunnya mutu, terganggunya kontinutas produksi serta menurunnya pendapatan petani. Oleh karena itu, program peningkatan produksi pertanian perlu terus digerakkan dengan dukungan pertanian yang unggul dan terbebas dari serangan hama dan penyakit.

Salah satu solusi untuk mengatasi permasalahan hama dan penyakit adalah dengan penggunaan pestisida sebagai sarana pendukung produksi pertanian, sehingga ketersediaan pestisida perlu terus diperhatikan. Kebutuhan ini menunjukkan bahwa pestisida memiliki prospek yang baik untuk terus tumbuh dan berkembang dalam lingkungan industri agrokimia di Indonesia. PT. Agricon merupakan salah satu perusahaan yang memproduksi pestisida berupa herbisida, fungisida, insektisida dan rodentisida. Dalam hal ini, PT. Agricon memerlukan rantai pasok yang kokoh sehingga dapat mendukung tercapainya tujuan perusahaan. Suatu rantai pasok didefinisikan sebagai suatu jaringan yang terdiri atas beberapa perusahaan (meliputi supplier, manufacturer, distributor dan retailer) yang bekerja sama dan terlibat baik secara langsung maupun tidak langsung dalam memenuhi permintaan pelanggan, dimana perusahaan-perusahaan tersebut melakukan fungsi pengadaan material, proses transformasi material menjadi produk setengah jadi dan produk jadi, serta distribusi produk jadi tersebut hingga ke konsumen akhir (Geraldin et al., 2007). Rantai pasok yang kokoh adalah rantai pasok yang mampu bertahan ketika dihadang oleh berbagai macam gangguan dan bencana yang tak terduga (Tang, 2006).

Disisi lain, dalam menjalankan rantai pasok suatu perusahaan akan dihadapkan dengan berbagai risiko pada rantai maupun para pelaku rantai pasok. Risiko adalah fungsi dari tingkat ketidakpastian dan dampak suatu kejadian (Sinha et al., 2004). Hendricks dan Singhal (2003) mengemukakan bahwa gangguan pada rantai pasok berdampak negatif dalam jangka panjang terhadap perusahaan dan banyak perusahaan yang tidak mampu pulih secara cepat dari dampak negatif tersebut. Selain itu, Craighead et al. (2007) berpendapat bahwa struktur rantai pasok mencakup faktor-faktor seperti kerapatan, kompleksitas dan node kritis yang dapat meningkatkan tingkat keparahan gangguan rantai pasok.

Indikasi risiko yang dialami PT. Agricon di antaranya kesalahan perencanaan, gangguan mesin operasi, serta kendala bahan baku impor dari
Tiongkok dan Jepang yang menyebabkan ketidakmampuan dalam memenuhi kebutuhan dan jadwal pelanggan. Oleh karena itu, risiko menjadi ancaman yang terjadi baik secara internal maupun eksternal yang akan berpengaruh negatif terhadap pencapaian sasaran perusahaan (Goh et al., 2007), sehingga diperlukan manajemen risiko rantai pasok yang terkelola dengan baik sehingga perusahaan mampu bertahan, meminimalkan risiko dan menjaga agar sistem rantai pasok tidak terganggu (Norrman dan Jansson, 2004).

Berdasarkan permasalahan tersebut maka tujuan penelitian ini mengidentifikasi dan menganalisis mekanisme rantai pasok serta kinerja rantai pasok pestisida dan mengidentifikasi serta menganalisis risiko pada rantai pasok pestisida. Hasil penelitian ini diharapkan dapat menjadi masukan bagi pengambil kebijakan dan pelaku rantai pasok dalam meningkatkan kinerjanya. Lokasi kajian yaitu pada industri pestisida nasional di PT. Agricon yang berlokasi di Bogor, Jawa Barat.

\section{METODE PENELITIAN}

\section{Kerangka Pemikiran}

Analisis risiko rantai pasok pestisida diawali dengan permasalahan peningkatan produksi pertanian yang mendukung ketahanan pangan di Indonesia. Peningkatan produksi pertanian harus didukung oleh pertanian yang unggul dan terbebas dari hama dan penyakit, oleh karena itu ketersediaan pestisida sebagai sarana pendukung produksi pertanian perlu diperhatikan dan dikaji lebih lanjut untuk mengurangi risiko potensial yang mungkin muncul pada rantai pasok pestisida. Upaya tersebut dapat dilakukan dengan mengoptimalkan manajemen risiko rantai pasok pestisida sehingga tercipta integrasi hulu dan hilir rantai pasok yang efektif dan efisien. Analisis risiko dilakukan dengan mengidentifikasi dan analisis mekanisme rantai pasok pestisida serta kinerja rantai pasok pestisida, sehingga dapat diketahui tingkat kinerja manajemen rantai pasok pestisida. Selanjutnya dilakukan identifikasi risiko dalam rantai pasok berdasarkan kondisi di lapangan, kemudian dilanjutkan dengan proses analisis dan evaluasi risiko rantai pasok pestisida, sehingga dapat ditentukan alternatif mitigasi risiko (Gambar 1).

\section{Teknik Pengumpulan Data}

Penelitian ini menggunakan data primer dan data sekunder. Data tersebut diperoleh melalui: 1). Studi pustaka terkait dengan konsep manajemen rantai pasok, konsep identifikasi dan penilaian risiko rantai pasok, 2). Observasi lapang untuk melihat secara langsung aktivitas yang berkaitan dengan manajemen dan aktivitas rantai pasok pestisida serta risiko yang terjadi pada rantai pasok pestisida. 3). wawancara mendalam untuk memperoleh informasi yang akurat serta untuk mengklarifikasi permasalahan dan konfigurasi rantai pasok yang ditemukan di lapangan. 


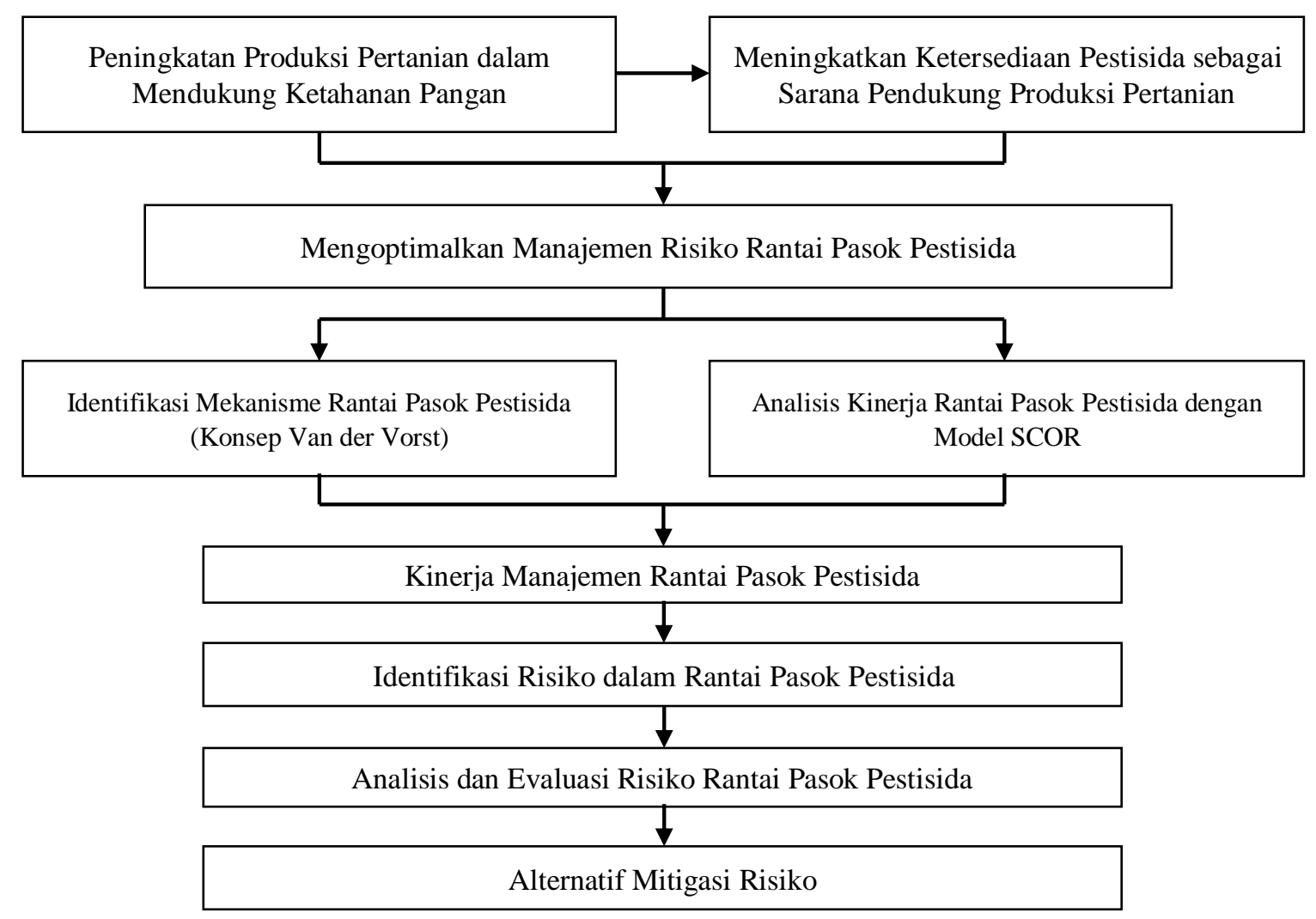

Gambar 1. Kerangka pemikiran penelitian

Pengambilan data ke 4 melalui pendapat pakar yang diperoleh secara langsung dari pakar (baik praktisi maupun akademisi) berdasarkan pada keahlian di bidang pestisida untuk mensintesis kondisi melalui kuesioner dan wawancara terkait dengan risiko rantai pasok pestisida sebanyak 5 (lima) orang yang berasal dari praktisi pada PT. Agricon, dosen Institut Pertanian Bogor dan anggota Komisi Pestisida Kementerian Pertanian.

Tahapan dalam pengumpulan data diawali dengan studi pustaka terkait industri pestisida, kemudian observasi lapang di PT. Agricon baik pada kantor pusat di Kota Bogor maupun pabrik di Desa Wanaherang untuk lebih memahami aktivitas yang terjadi pada rantai pasok pestisida. Tahapan selanjutnya wawancara mendalam untuk mengkonfigurasi rantai pasok pestisida, identifikasi risiko dan aksi mitigasi dalam rangka menanggulangi risiko yang mungkin timbul kepada beberapa bagian dalam rantai pasok pestisida. Hasil observasi lapang dan wawancara menjadi dasar dalam penyusunan kuesioner House of Risk 1 (HOR 1) untuk analisis dan evaluasi risiko rantai pasok pestisida. Setelah data kuesioner HOR 1 terkumpul, dilakukan pengolahan data dengan Microsoft Excel dan hasil olah data tersebut digunakan sebagai input dalam penyusunan kuesioner HOR 2 berupa aksi mitigasi risiko rantai pasok pestisida. Kuesioner HOR 2 yang telah terkumpul diolah dengan Microsoft Excel, sehingga diperoleh hasil prioritas aksi mitigasi risiko.

\section{Metode Pengolahan dan Analisis Data}

Metode analisis data yang digunakan pada penelitian ini antara lain : 1) identifikasi dan analisis mekanisme rantai pasok pestisida dengan menggunakan kerangka analisis Van der Vorst, 2) analisis dan pengukuran kinerja rantai pasok pestisida dilakukan dengan menggunakan model Supply Chain Operations Reference (SCOR), 3) identifikasi risiko rantai pasok pestisida berdasarkan elemen SCOR dengan pendekatan Failure Mode Effect Analysis (FMEA) dan 4) analisis dan evaluasi risiko rantai pasok pestisida dengan menggunakan HOR 1.

Mekanisme rantai pasok dianalisis berdasarkan kerangka analisis Van der Vorst melalui 4 (empat) elemen utama, yaitu a) struktur jaringan rantai pasok, b) proses bisnis rantai pasok, c) sumber daya rantai pasok, dan d) manajemen rantai pasok (Gambar 2). 


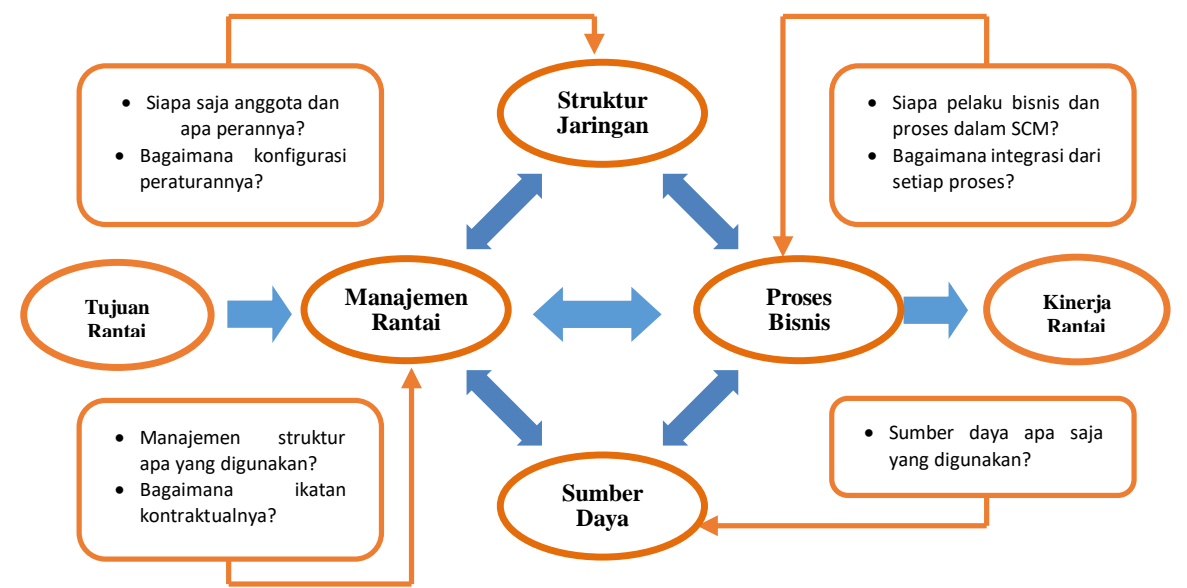

Gambar 2. Kerangka analisis rantai pasok (Van der Vorst, 2006)

Model SCOR adalah suatu metode yang dikembangkan oleh Supply Chain Council sebagai alat diagnosa manajemen rantai pasok yang digunakan untuk mengukur performa atau kinerja rantai pasok perusahaan (Pujawan, 2005). Jamehshooran et al. (2015) juga mengemukakan bahwa model SCOR merupakan sistem untuk mengukur kinerja pada setiap level dalam proses bisnis rantai pasok meliputi perencanaan, pengadaan, pengolahan, pengiriman dan pengembalian. Oleh karena itu, analisis kinerja rantai pasok diawali dengan pemodelan referensi SCOR melalui pemeriksaan 5 (lima) indikator proses bisnis, yaitu plan, source, make, deliver dan return (Georgise et al., 2013). Kemudian pengukuran kinerja rantai pasok pada matriks-matriks kinerja berdasarkan data aktual dari indikator kinerja yang dibandingkan dengan target tertinggi perusahaan untuk meningkatkan nilai objektif kinerja perusahaan (proses benchmarking kinerja rantai pasok perusahaan) dan dari hasil data aktual matriks kinerja dikalikan persentase pencapaian perusahaan.

Tahap terakhir adalah melakukan perhitungan nilai total pengukuran kinerja rantai pasok yang digunakan untuk mengklasifikasikan nilai standar kinerjanya sesuai dengan standar tertentu. Dasar penentuan klasifikasi nilai standar kinerja ditentukan berdasarkan klasifikasi Monczka et al. (2011), yaitu 1) nilai kinerja 95-100 sebagai kriteria sangat baik (excellent); 2) nilai kinerja 90-94 sebagai kriteria baik (above average); 3) nilai kinerja 80-89 sebagai kriteria sedang (average); 4) nilai kinerja 70-79 sebagai kriteria kurang (below average); 5) nilai kinerja 60-69 sebagai kriteria sangat kurang (poor); dan 6) nilai kinerja < 60 sebagai kriteria buruk (unacceptable).

Analisis risiko rantai pasok pestisida diawali dengan identifikasi kejadian risiko dan sumber risiko, analisis risiko dengan memberikan penilaian risiko dan evaluasi risiko yaitu penentuan nilai Aggregate
Risk Potential (ARP) yang kemudian dilakukan pemeringkatan (ranking). Risiko rantai pasok diidentifikasi dan dikaji berdasarkan dampak dari kejadian serta tingkat kejadiannya berdasarkan pendekatan FMEA dan diidentifikasi berdasarkan proses bisnis model SCOR. Penilaian risiko dilakukan dengan menentukan nilai severity (keparahan) yang ditimbulkan oleh kejadian risiko, menentukan occurrence (frekuensi) dari sumber risiko, menentukan correlation (korelasi) antara kejadian risiko dan sumber risiko, menentukan hubungan/keterkaitan antara sumber risiko, serta menghitung nilai ARP.

Penentuan nilai severity menggunakan skala 1-10 (tidak ada efek kegagalan-pasti terjadi efek kegagalan), nilai occurence menggunakan skala 1-10 (hampir tidak pernah terjadi-sering terjadi), nilai correlation (hubungan antara kejadian risiko dengan sumber risiko) menggunakan skala 0 yang berarti tidak ada korelasi, nilai 1 korelasi rendah, nilai 3 korelasi sedang dan nilai 9 korelasi tinggi dan nilai hubungan/keterkaitan antara risk agent yaitu 0 menunjukkan tidak ada korelasi dan $\theta$, *, • menunjukkan berturut-turut lemah, sedang dan kuat. Hubungan korelasi dinyatakan sebagai $\mathrm{R}_{\mathrm{ij}} \in\{0,1\}$, untuk $\mathrm{R}_{\mathrm{ij}}=1$ maka terdapat korelasi antara risiko $\mathrm{i}$ dengan agen risiko $\mathrm{j}$ dan $\mathrm{R}_{\mathrm{ij}}=0$ apabila tidak terdapat korelasi antara risiko i dan agen risiko $\mathrm{j}$. Rumus kombinasi pakar yang digunakan adalah (Hora et al., 2013):

$S_{i} \quad=$ median $\left[S i_{1}, S i_{2}, \ldots, S i_{k}\right] \quad \forall i$

$O_{j} \quad=$ median $\left[\mathrm{Oj}_{1}, \mathrm{Oj}_{2}, \ldots, \mathrm{Oj}_{k}\right] \quad \forall j$

$\mathrm{S}_{\mathrm{i}} \quad$ = Tingkat dampak suatu risiko (severity level of risk)

$\mathrm{O}_{\mathrm{j}} \quad=$ Tingkat kemunculan/frekuensi risiko (occurence level of risk)

$i, j \quad=1,2, \ldots, \mathrm{n}$

$\mathrm{k}=$ Penilaian orang ke- $\mathrm{k}$

Pujawan dan Geraldine (2009) menyatakan bahwa ARP dapat dirumuskan jika $\mathrm{O}_{\mathrm{j}}$ adalah 
kemungkinan dari kejadian sumber risiko $\mathrm{j}, \mathrm{S}_{\mathrm{i}}$ adalah keparahan dari pengaruh kejadian risiko ke-i dan $R_{i j}$ adalah korelasi antara kejadian risiko $\mathrm{i}$ dengan sumber risiko j, maka $\mathrm{ARP}_{\mathrm{j}}$ (Aggregate Risk Potentials of risk agent $j$ ) dirumuskan menjadi :

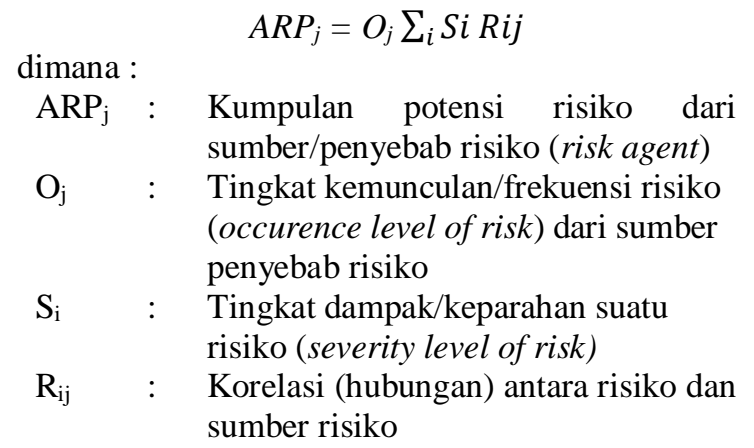

Evaluasi risiko bertujuan untuk menentukan ranking $\mathrm{ARP}_{\mathrm{j}}$, menentukan prioritas risiko berdasarkan nilai $\mathrm{ARP}_{\mathrm{j}}$ dari terbesar hingga terkecil, menentukan dampak (potentials impact) yang mungkin timbul dari risk event dan membuat korelasi antar sumber risiko (risk agent) yang dijadikan sebagai komponen atap didalam matriks House of Risk 1. Setelah diperoleh hasil analisis risiko berupa nilai $\mathrm{ARP}_{\mathrm{j}}$ kemudian dilakukan pemeringkatan (ranking) dengan menggunakan rumus (Geraldine et al,. 2007) sebagai berikut :

$$
P_{j}=O_{j} \sum_{i=1}^{n} \operatorname{Six}(\operatorname{Rij} x w i j) \quad \forall j
$$

$$
\begin{array}{lll}
\text { dimana : } & \\
\mathrm{P}_{\mathrm{j}} & : & \begin{array}{l}
\text { Prioritas risiko (risk priority index) } \\
\mathrm{O}_{\mathrm{j}}
\end{array} \\
& : & \begin{array}{l}
\text { Tingkat kemunculan/frekuensi risiko } \\
\text { (occurence level of risk) dari sumber } \\
\text { risiko }
\end{array} \\
j & : & 1,2, \ldots, \mathrm{m} ; \mathrm{R}_{\mathrm{ij}} \in\{0,1\} \\
\mathrm{S}_{\mathrm{i}} & : & \begin{array}{l}
\text { Tingkat dampak/keparahan suatu } \\
\text { risiko (severity level of risk) }
\end{array} \\
\mathrm{R}_{\mathrm{ij}} & : & \begin{array}{l}
\text { Korelasi (hubungan) antara risiko } i \\
\text { dengan sumber risiko } j
\end{array} \\
\mathrm{~W}_{\mathrm{ij}} & : & \begin{array}{l}
\text { Bobot korelasi antara risiko } i \text { dengan } \\
\text { sumber risiko } j
\end{array}
\end{array}
$$

Nilai ARP yang dihasilkan tidak seluruhnya dilakukan penanganan/pengelolaan risiko, tetapi menggunakan prinsip Pareto yang dikenal juga sebagai aturan 80 : 20 yang menggambarkan pengurutan nilai ARP dari kiri ke kanan yang dapat membantu menemukan permasalahan terpenting agar segera diselesaikan dan dilakukan aksi mitigasi atau pencegahan (Ulfah, 2016)

\section{HASIL DAN PEMBAHASAN}

\section{Mekanisme Rantai Pasok Pestisida}

Struktur Jaringan Rantai Pasok Pestisida

Aliran umum yang terjadi pada rantai pasok terbagi menjadi aliran produk (garis penuh) dan aliran informasi (garis putus-putus). Secara umum, struktur jaringan rantai pasok pestisida pada PT. Agricon dapat dilihat pada Gambar 3.

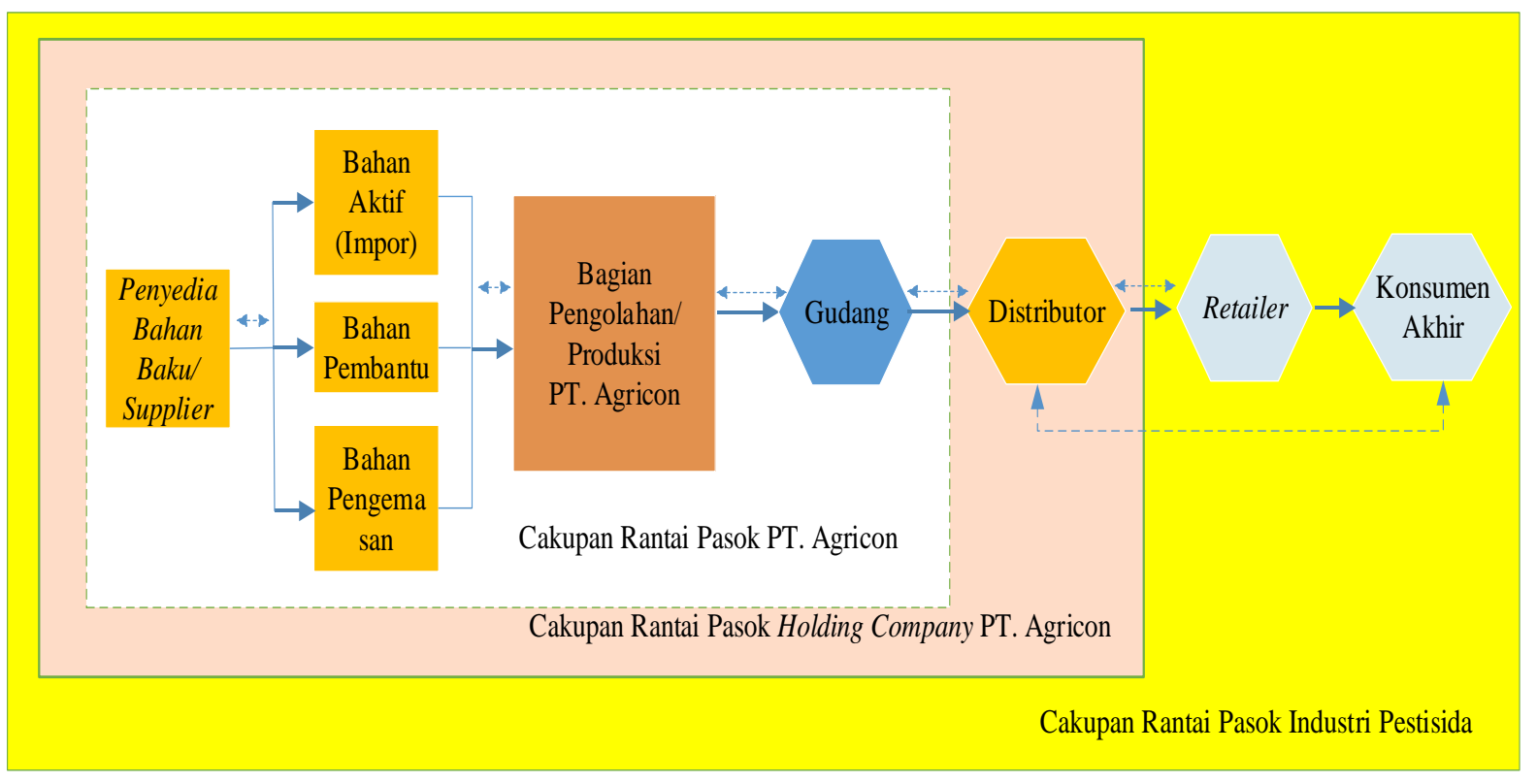

Gambar 3. Struktur jaringan rantai pasok pestisida PT. Agricon 


\section{Anggota Rantai Pasok}

Anggota primer rantai pasok pestisida pada PT. Agricon yaitu penyedia bahan baku/supplier, bagian pengolahan/produksi, distributor, retailer dan konsumen akhir. Penyedia bahan baku/supplier utama berupa bahan aktif berasal dari luar negeri, yaitu $80 \%$ dari Tiongkok dan $20 \%$ sisanya berasal dari Jepang, Belgia, Korea, Jerman dan Malaysia, sedangkan bahan pembantu dan bahan pengemasan berasal dari pemasok lokal dalam negeri. Proses pengolahan/produksi pestisida meliputi penentuan produk pestisida, persiapan bahan, proses formulasi, pengemasan produk, pengkodean, pelabelan, pengepakan dan penyimpanan. Tidak seluruh proses pengolahan pestisida dilakukan oleh mesin, sebagian besar masih menggunakan tenaga manusia untuk pengontrolan dan pengecekan proses serta kualitas produk. Proses pengolahan pestisida diakhiri dengan penyimpanan produk jadi di gudang pabrik atau didistribusikan ke pusat distribusi.

Distributor dalam rantai pasok pestisida adalah Sub Business Unit (SBU) PT. Agricon, yaitu PT. Agricon Indonesia (PT. ACI). PT. ACI memiliki tanggung jawab untuk menginformasikan pesanan produk pestisida ke PT. Agricon serta mengontrol pendistribusiannya ke retailer atau langsung ke konsumen akhir. Retailer dalam rantai pasok pestisida merupakan pedagang dengan skala besar dan skala kecil. Retailer inilah yang sebagian besar menjembatani tersampaikannya produk pestisida dari distributor ke konsumen akhir. Konsumen akhir merupakan pihak yang memanfaatkan produk pestisida, salah satunya adalah petani yang menggunakan produk pestisida untuk kebutuhan pribadi tanpa diperdagangkan kembali.

\section{Entitas Rantai Pasok}

Entitas rantai pasok terdiri dari produk dan pasar. Produk pestisida PT. Agricon terdiri dari insektisida, herbisida, fungisida, rodentisida, moluksida, akarisida dan lain-lain. Produk-produk pestisida PT. Agricon disajikan pada Tabel 1. Pestisida yang diproduksi oleh PT. Agricon memiliki 2 (dua) jenis kemasan, yaitu cairan dalam bentuk botol atau jerigen dan serbuk (powder) dalam kemasan bungkus. Jumlah produksi formulasi pestisida pada kurun waktu 2013-2017 dapat dilihat pada Tabel 2 .

Tabel 1. Produk pestisida PT. Agricon

\begin{tabular}{|c|c|c|c|c|c|c|}
\hline Insektisida & Herbisida & Fungisida & Rodentisida & Moluksida & Akarisida & Lain-Lain \\
\hline Sevin $85 \mathrm{SP}$ & Aladin $865 \mathrm{SL}$ & $\begin{array}{l}\text { Bazoka } \\
\text { 80WP }\end{array}$ & $\begin{array}{l}\text { Ratgone } 0.005 \\
\text { BB }\end{array}$ & $\begin{array}{l}\text { Snaildown } \\
250 \mathrm{EC}\end{array}$ & $\begin{array}{l}\text { Nebijin } 0.3 \\
\text { DP }\end{array}$ & Rosasol - N \\
\hline $\begin{array}{l}\text { Mospilan } 30 \\
\text { EC }\end{array}$ & Win $10 \mathrm{WP}$ & $\begin{array}{l}\text { Brilliant } 72 \\
\text { WP }\end{array}$ & & & & Rosasol - P \\
\hline Cakram 25 EC & Win $20 \mathrm{WG}$ & $\begin{array}{l}\text { Throne } 250 \\
\text { EC }\end{array}$ & & & & Rosasol - K \\
\hline Meteor $25 \mathrm{EC}$ & $\begin{array}{l}\text { Teracon } 100 \\
\text { SC }\end{array}$ & Blast $200 \mathrm{SC}$ & & & & $\begin{array}{l}\text { Rosasol - } \\
\text { Even }\end{array}$ \\
\hline Sniper 50 EC & Crash 480 SL & Inari $72 \mathrm{WP}$ & & & & Widecoat \\
\hline $\begin{array}{l}\text { Ultimax } 550 \\
\text { EC }\end{array}$ & Trabas $150 \mathrm{SL}$ & $\begin{array}{l}\text { Captive } 200 \\
\text { SC }\end{array}$ & & & & \\
\hline $\begin{array}{l}\text { Spontan } 400 \\
\text { SL }\end{array}$ & Etron $670 \mathrm{EC}$ & & & & & \\
\hline Maxima 68 & Breeze & & & & & \\
\hline WP & $270 / 120 \mathrm{SL}$ & & & & & \\
\hline $\begin{array}{l}\text { Abuki } 50 \text { SL } \\
\text { Applaud } 440 \\
\text { SC } \\
\text { Tenchu } 20 \text { SG }\end{array}$ & & & & & & \\
\hline
\end{tabular}

Sumber : PT. Agricon 2018

Tabel 2. Jumlah produksi formulasi pestisida pada PT. Agricon

\begin{tabular}{lccccc}
\hline \multirow{2}{*}{ Jenis } & \multicolumn{5}{c}{ Jumlah Produksi (Kg-Liter) } \\
\cline { 2 - 6 } Pestisida & $\mathbf{2 0 1 7}$ & $\mathbf{2 0 1 6}$ & $\mathbf{2 0 1 5}$ & $\mathbf{2 0 1 4}$ & $\mathbf{2 0 1 3}$ \\
\hline Insektisida & $2.079 .481,65$ & $1.685 .397,60$ & 1.132 .944 & $1.912 .174,85$ & $1.825 .980,70$ \\
Herbisida & 1.612 .778 & $1.734 .468,47$ & 1.837 .331 & $1.907 .480,30$ & 1.076 .560 \\
Fungisida & $528.962,80$ & $537.466,10$ & $280.988,80$ & $438.724,10$ & $385.786,15$ \\
Rodentisida & 610.171 & $454.225,20$ & $366.876,40$ & $776.894,80$ & 381.543 \\
\hline
\end{tabular}

Sumber : PT. Agricon 2018 
Jangkauan pasar PT. Agricon adalah perusahaan generik dan retailer. Area penjualan dan pelayanan produk pestisida di Indonesia dibagi menjadi 11 wilayah, 44 dealer dan 340 sub dealer. Pesaing terbesar PT. Agricon yaitu PT. Sygenta, PT. Bayer, dan PT. Nufarm. Pasar pestisida Indonesia tahun 2017 mencapai Rp 3,5 Triliun dan PT. Agricon mencapai pangsa pasar senilai Rp 360 Milyar (10\%) dari pangsa pasar pestisida nasional. Pada tahun 2016, PT. Agricon mulai melakukan penjualan ekspor rodentisida sebanyak $94.020 \mathrm{~kg}$ ke negara Malaysia dan herbisida sebanyak 32.000 liter ke negara Thailand. Jumlah penjualan pestisida PT. Agricon dalam kurun waktu 2013-2017 disajikan pada Tabel 3.

\section{Proses Bisnis Rantai Pasok Pestisida \\ Tinjauan Siklus}

Anggota rantai pasok pestisida pada PT. Agricon terdiri dari 3 (tiga) tingkatan, yaitu pemasok bahan baku, perusahaan pengolah/produksi serta distributor. Siklus pengadaan berupa kegiatan perencanaan pemesanan bahan baku, kegiatan pemesanan ke pemasok dan pengiriman bahan baku. Siklus produksi berlangsung selama jangka waktu tertentu sesuai dengan jadwal yang telah ditetapkan. Siklus pesanan dapat terjadi sepanjang waktu dalam kurun waktu satu tahun berdasarkan surat Delivery $\operatorname{Order}(\mathrm{DO})$.

\section{Tinjauan Dorong/Tarik}

Tinjauan dorong/tarik pada rantai pasok dibedakan berdasarkan keputusan untuk mengeksekusi proses baik bersifat reaktif maupun spekulatif dari pesanan yang akan masuk (Abror $e t$ al., 2011). Proses tarik terjadi pada siklus pesanan konsumen yang berarti siklus ini dieksekusi setelah adanya pesanan masuk dari konsumen. Siklus pesanan konsumen yaitu penerimaan Purchase Order (PO) yang diubah menjadi Sales Order (SO) kemudian diubah menjadi Delivery Order (DO) berdasarkan ketersediaan stok. Proses dorong terjadi pada siklus produksi dan siklus pengadaan yang berarti proses dilakukan untuk mengantisipasi pesanan yang akan masuk. Siklus produksi dilakukan sesuai dengan perencanaan jadwal bergantung ketersediaan bahan baku, sedangkan siklus pengadaan dilaksanakan apabila stok bahan baku menipis dengan memperhatikan faktor biaya dan waktu pengiriman.

\section{Sumber Daya Rantai Pasok Pestisida Sumber Daya Fisik}

Sumber daya fisik terdiri dari adanya kantor pusat di Kota Bogor untuk mengurus segala prosedur teknis dan kegiatan administrasi, pabrik pengolahan dan 4 (empat) unit gudang di Desa WanaherangBogor, serta pusat distribusi di 3 (tiga) daerah, yaitu Medan, Makassar dan Surabaya. Sumber daya fisik lainnya yang digunakan untuk menghasilkan produk pestisida adalah alat dan mesin, baik mesin formulasi dan mesin pengemasan. Jenis teknologi yang digunakan adalah pemanfaatan aplikasi Enterprise Resource Planning (ERP) untuk mengontrol pesanan produk.

\section{Sumber Daya Manusia}

Manajemen PT. Agricon dipimpin oleh seorang Direktur dan didukung oleh beberapa manajer. Ketenagakerjaan di PT. Agricon secara umum dibagi menjadi 2 (dua), yaitu karyawan tetap dan karyawan tidak tetap/kontrak. Jumlah karyawan per Maret 2018 sebanyak 1.696 orang yang terdiri dari 1.004 orang karyawan tetap dan 692 orang karyawan tidak tetap/kontrak. Karyawan kontrak dibagi menjadi 3 (tiga) yaitu karyawan kontrak 2 (dua) tahunan, karyawan kontrak 1 (satu) tahunan, dan karyawan kontrak 30 hari.

\section{Manajemen Rantai Pasok Pestisida \\ Kesepakatan Kontraktual}

Kesepakatan kontraktual yang terjalin adalah kontrak dengan pemasok bahan baku yang dikirim dari luar negeri. Kesepakatan kontrak ini terjalin dengan pemasok baru, selanjutnya kesepakatan kontraktual dibatalkan dan diganti menjadi proforma invoice apabila telah menjadi langganan. Isi kontrak berupa jumlah pesanan, negosiasi harga, metode atau termin pembayaran, jangka waktu pengiriman pesanan, jalur distribusi, serta hak dan kewajiban kedua belah pihak

Tabel 3. Jumlah penjualan pestisida pada PT. Agricon

\begin{tabular}{lccccc}
\hline \multicolumn{1}{c}{ Jenis } & \multicolumn{5}{c}{ Jumlah Penjualan (Kg-Liter) } \\
\cline { 2 - 6 } Pestisida & $\mathbf{2 0 1 7}$ & $\mathbf{2 0 1 6}$ & $\mathbf{2 0 1 5}$ & $\mathbf{2 0 1 4}$ & $\mathbf{2 0 1 3}$ \\
\hline Insektisida & $2.097 .595,50$ & $1.685 .420,20$ & $1.012 .493,90$ & $1.644 .485,10$ & $1.580 .354,74$ \\
Herbisida & $1.662 .766,22$ & $1.722 .288,08$ & 1.801 .355 & 1.828 .948 & 1.074 .656 \\
Fungisida & $553.775,34$ & $540.332,85$ & $261.610,90$ & $386.944,40$ & $319.216,30$ \\
Rodentisida & 608.031 & 453.973 & $341.465,60$ & $642.355,60$ & $376.218,90$ \\
\hline
\end{tabular}

Sumber : PT. Agricon 2018 


\section{Sistem Transaksi}

Sistem transaksi terjadi pada manajemen bahan baku dan penjualan produk. Transaksi pada proses pengadaan bahan baku dibuktikan dengan surat transaksi Bagian Supply Chain. Aliran transaksi pada proses pengadaan bahan baku disajikan pada Gambar 4, sedangkan aliran transaksi pada proses penjualan produk pestisida disajikan pada Gambar 5 .

\section{Pengukuran Kinerja Rantai Pasok Pestisida}

Dari kartu SCOR (Tabel 4) dapat diketahui bahwa nilai matrik pemenuhan pesanan sempurna sebesar 99,39\%, yaitu hampir seluruh pesanan yang masuk dapat dipenuhi secara sempurna dan hanya sekitar $0,61 \%$ pesanan yang tidak terpenuhi secara penuh ataupun tidak terpenuhi sama sekali. Jika konsumen hendak memesan pestisida maka harus menunggu selama 12 hari hingga pesanan tersebut terkirim. Pada matrik fleksibilitas rantai pasok atas, apabila terdapat peningkatan pesanan sebanyak $20 \%$ dari total produk yang dikirim maka PT. Agricon mampu memenuhinya dalam waktu 3 (tiga) hari hingga pestisida diterima oleh konsumen. Pada matrik penyesuaian rantai pasok atas, PT. Agricon mampu meningkatkan ketersediaan stok pestisida hingga mencapai $11,72 \%$ dari total kapasitas produksi dalam kurun waktu 30 hari, sedangkan nilai untuk matrik penyesuaian rantai pasok bawah adalah sebesar 0\% yang menunjukkan bahwa apabila PT. Agricon menurunkan kapasitas produksinya hingga $0 \%$ maka tidak akan dikenakan denda biaya maupun pinalti.

Data pembanding (benchmark) kinerja yang digunakan merupakan target perusahaan. Berdasarkan kartu SCOR benchmark pada Tabel 5, matrik pemenuhan pesanan sempurna telah memiliki nilai yang melebihi dari target perusahaan yaitu $+3,39 \%$, sehingga hal ini perlu dipertahankan dan diharapkan dapat terpenuhi seluruhnya (100\%). Target siklus pemenuhan pesanan perlu pengurangan 12 hari dan pengurangan sebanyak 2 (dua) hari untuk matrik fleksibilitas rantai pasok atas, serta target pencapaian matrik penyesuaian rantai pasok atas sebesar $88,28 \%$.

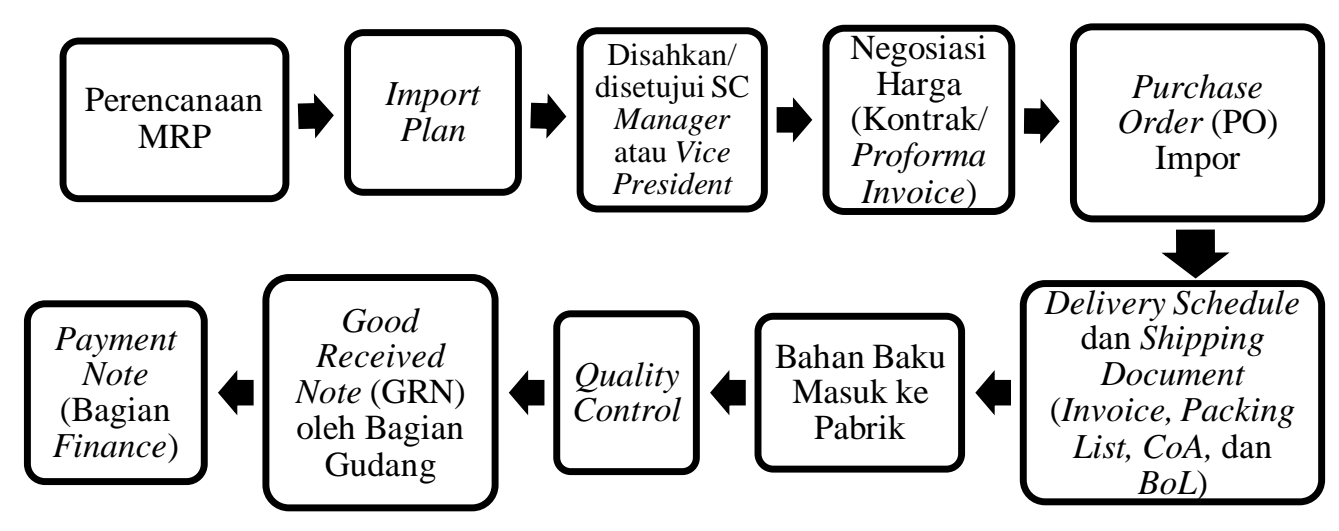

Gambar 4. Aliran transaksi pada proses pengadaan bahan baku

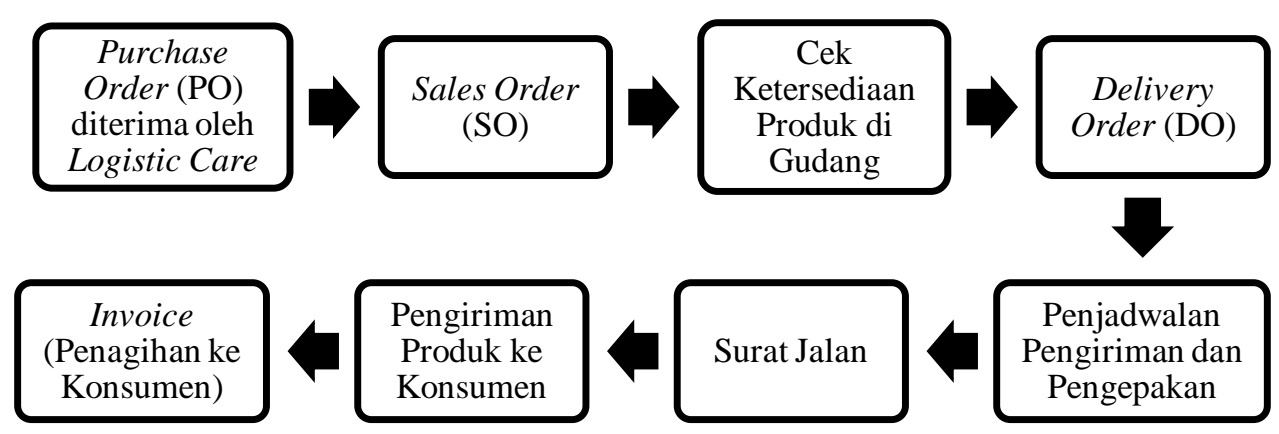

Gambar 5. Aliran transaksi pada proses penjualan produk pestisida 
Tabel 4. Kartu SCOR PT. Agricon

\begin{tabular}{cccc}
\hline Atribut Kinerja & Tinjauan Matrik & Matrik SCOR Level 1 & Aktual \\
\hline & Reliabilitas Rantai Pasok & Pemenuhan Pesanan Sempurna & $99,39 \%$ \\
Eksternal & Responsivitas & Siklus Pemenuhan Pesanan & 12 hari \\
& & Fleksibilitas Rantai Pasok Atas & 3 hari \\
& Ketangkasan & Penyesuaian Rantai Pasok Atas & $11,72 \%$ \\
& & Penyesuaian Rantai Pasok Bawah & $0 \%$ \\
& Biaya & Biaya Total Manajemen Rantai & $83 \%$ \\
Internal & Aset & Biaya Pokok Produk & $72 \%$ \\
& \multirow{2}{*}{ Aset } & Siklus Cash-to-Cash & 120 hari \\
& & Return on SC Fixed Assets & -
\end{tabular}

Tabel 5. Kartu SCOR (SCOR-Card) benchmark PT. Agricon

\begin{tabular}{|c|c|c|c|c|c|c|}
\hline $\begin{array}{l}\text { Atribut } \\
\text { Kinerja }\end{array}$ & $\begin{array}{c}\text { Tinjauan } \\
\text { Metrik }\end{array}$ & $\begin{array}{l}\text { Metrik SCOR } \\
\text { Level } 1\end{array}$ & Aktual & Advantage & Superior & $\begin{array}{c}\text { Requirements } \\
\text { Gap }\end{array}$ \\
\hline \multirow{5}{*}{ Eksternal } & $\begin{array}{l}\text { Reliabilitas } \\
\text { Rantai Pasok }\end{array}$ & $\begin{array}{c}\text { Pemenuhan } \\
\text { Pesanan } \\
\text { Sempurna }\end{array}$ & $99,39 \%$ & $90 \%$ & $96 \%$ & $+3,39 \%$ \\
\hline & Responsivitas & $\begin{array}{c}\text { Siklus } \\
\text { Pemenuhan } \\
\text { Pesanan }\end{array}$ & 12 hari & 5 hari & 0 hari & -12 hari \\
\hline & \multirow{3}{*}{ Ketangkasan } & $\begin{array}{c}\text { Fleksibilitas } \\
\text { Rantai Pasok } \\
\text { Atas }\end{array}$ & 3 hari & 1 hari & 0 hari & -2 hari \\
\hline & & $\begin{array}{c}\text { Penyesuaian } \\
\text { Rantai Pasok } \\
\text { Atas }\end{array}$ & $11,72 \%$ & $30 \%$ & $100 \%$ & $-88,28 \%$ \\
\hline & & $\begin{array}{c}\text { Penyesuaian } \\
\text { Rantai Pasok } \\
\text { Bawah }\end{array}$ & $0 \%$ & $0 \%$ & $0 \%$ & $0 \%$ \\
\hline \multirow{5}{*}{ Internal } & \multirow{3}{*}{ Biaya } & $\begin{array}{l}\text { Biaya Total } \\
\text { Manajemen }\end{array}$ & $83 \%$ & & \multirow{5}{*}{60 hari } & \\
\hline & & Rantai Pasok & & & & \\
\hline & & $\begin{array}{l}\text { Biaya Pokok } \\
\text { Produk }\end{array}$ & $72 \%$ & & & \\
\hline & \multirow{2}{*}{ Aset } & $\begin{array}{c}\text { Siklus Cash-to- } \\
\text { Cash }\end{array}$ & 120 hari & 100 hari & & -60 hari \\
\hline & & $\begin{array}{c}\text { Return on SC } \\
\text { Fixed Assets }\end{array}$ & - & & & \\
\hline
\end{tabular}

Tahap selanjutnya adalah melakukan penilaian kinerja rantai pasok pestisida yang diperoleh dari perkalian antara bobot masing-masing matrik kinerja (hasil penilaian gabungan tiga (3) pendapat pakar) dengan persentase nilai pencapaian aktual perusahaan, serta melakukan perhitungan nilai total pengukuran kinerja untuk mengklasifikasikan nilai standar kinerjanya. Nilai total hasil pengukuran kinerja rantai pasok pestisida tersaji pada Tabel 6 .

Berdasarkan hasil perhitungan pada Tabel 6 , diketahui bahwa tingkat kinerja rantai pasok pestisida PT. Agricon sebesar 52,69\%. Nilai tersebut menunjukkan bahwa kinerja rantai pasok pestisida berada pada kriteria buruk (unacceptable). Dari hasil tersebut diketahui bahwa tingkat kinerja rantai pasok pestisida masih sangat rendah, sehingga menyebabkan terjadinya kehilangan kesempatan (lost opportunity) yang mengakibatkan kehilangan keuntungan (profit loss) pada perusahaan.

Perbaikan kinerja terletak pada atribut kinerja responsivitas, ketangkasan dan aset. Pada atribut responsivitas, perusahaan dianggap belum cepat tanggap dalam mengontrol dan merespon adanya pesanan yang masuk dikarenakan konsumen masih harus menunggu dalam jangka waktu yang cukup lama sampai pesanan diterima. Selanjutnya adalah atribut ketangkasan pada matrik fleksibilitas rantai pasok atas dan penyesuaian rantai pasok atas, PT. Agricon belum mampu untuk memenuhi kapasitas produksi maksimal yang disebabkan adanya kesenjangan ketersediaan bahan baku dibandingkan dengan rancangan produksi serta waktu dan proses yang panjang dalam pemesanan bahan baku yang berimplikasi pada target produksi tidak tercapai. 
Untuk atribut aset pada matrik siklus cash-to-cash masih perlu dievaluasi lagi sehingga tercipta arus kas yang sehat dan efektif dalam pembiayaan perusahaan. Berdasarkan hal tersebut maka perbaikan yang perlu dilakukan dalam rangka peningkatan kinerja rantai pasok pestisida adalah melakukan perbaikan rancangan produksi, evaluasi kinerja pemasok, serta peningkatan koordinasi dan kerja sama dengan berbagai pihak yang terlibat dalam manajemen rantai pasok perusahaan sehingga tercipta desain rantai pasok pestisida yang efektif dan efisien.

\section{Identifikasi dan Analisis Risiko Rantai Pasok Pestisida}

Hasil Identifikasi Kemungkinan Terjadinya Risiko (Risk Event)

Identifikasi risiko pada setiap proses bisnis rantai pasok dilakukan berdasarkan pada dimensi SCOR, berupa proses perencanaan, pengadaan, pengolahan, pengiriman dan pengembalian yang diuraikan menjadi masing-masing sub proses sehingga kendala ataupun risiko yang biasa terjadi serta berpotensi untuk terjadi didalam rantai pasok dapat diketahui secara rinci (Septiani et al., 2016). Hasil identifikasi risiko diketahui bahwa diperoleh sejumlah 40 jenis kejadian risiko dalam aliran rantai pasok pestisida. Hasil identifikasi terjadinya risiko (risk event) dan hasil penilaian tingkat keparahan kejadian risiko (severity) dapat dilihat pada Tabel 7.

\section{Hasil Identifikasi Sumber Risiko (Risk Agent)}

Setiap kejadian risiko dapat terjadi karena adanya gangguan dari satu atau lebih dari sumber risiko, begitu pula setiap sumber risiko dapat menyebabkan satu atau lebih dari kejadian risiko
(Pujawan dan Geraldine, 2009). Hasil identifikasi sumber risiko (risk agent) dari rantai pasok pestisida diperoleh sebanyak 24 sumber risiko yang menyebabkan terjadinya 40 kejadian risiko dengan frekuensi kemungkinan terjadinya (occurence) seperti disajikan pada Tabel 8.

\section{Analisis Aggregate Risk Potentials (ARP)}

Analisis atau penilaian risiko merupakan alat untuk menghasilkan rasa berbagi urgensi dari risiko yang teridentifikasi dan untuk mengembangkan usaha mitigasi risiko (Sodhi dan Tang, 2012). Pemahaman tentang risiko didalam rantai pasok akan membantu dalam pembuatan keputusan yang lebih baik serta mengurangi risiko dalam keseluruhan jaringan rantai pasok (Hallikas et al., 2004). Penilaian risiko dilakukan dengan menentukan bobot dari setiap risiko berdasarkan penilaian pakar yang berpengalaman dibidang pestisida, sehingga menghasilkan nilai Aggregate Risk Potentials (ARP) yang digunakan untuk menentukan prioritas risiko yang memerlukan penanganan lebih lanjut. Hasil perhitungan nilai ARP disajikan pada Tabel 9

Berdasarkan Tabel 9 dapat diketahui hasil perhitungan prioritas nilai ARP untuk 24 sumber risiko. Peringkat tersebut menunjukkan bahwa nilai ARP tertinggi adalah terjadinya kerusakan pada alat dan mesin produksi (A8) dengan nilai ARP 3.560 sedangkan sumber risiko terendah adalah penumpukan stok produk jadi di gudang (A23) dengan nilai ARP sebesar 24. Dari peringkat nilai ARP tersebut dilakukan analisis diagram Pareto 80:20 terhadap prioritas sumber risiko terpenting agar segera diselesaikan. Diagram Pareto untuk prioritas sumber risiko disajikan pada Gambar 6

Tabel 6. Nilai kinerja rantai pasok pestisida PT. Agricon

\begin{tabular}{llccc}
\hline \multicolumn{1}{c}{ Atribut Kinerja } & \multicolumn{1}{c}{ Matrik Kinerja } & $\begin{array}{c}\text { Bobot } \\
\text { Matrik } \\
\text { Kinerja }\end{array}$ & $\begin{array}{c}\text { Nilai } \\
\text { Aktual }\end{array}$ & $\begin{array}{c}\text { \% Nilai } \\
\text { Matrik } \\
\text { Kinerja }\end{array}$ \\
\hline Reliabilitas Rantai Pasok & Pemenuhan Pesanan Sempurna & 0,19 & 100 & 19 \\
Responsivitas & Siklus Pemenuhan Pesanan & 0,17 & 8,33 & 1,42 \\
& Fleksibilitas Rantai Pasok Atas & 0,16 & 33,33 & 5,33 \\
Ketangkasan & Penyesuaian Rantai Pasok Atas & 0,08 & 11,72 & 0,94 \\
& Penyesuaian Rantai Pasok Bawah & 0,12 & 100 & 12 \\
Aset & Siklus Cash-to-Cash & 0,28 & 50 & 14 \\
\hline \multicolumn{2}{l}{ Nilai kinerja rantai pasok } & & & 52,69 \\
\hline
\end{tabular}


Tabel 7. Identifikasi kejadian risiko dan tingkat keparahan kejadian risiko

\begin{tabular}{|c|c|c|c|c|}
\hline $\begin{array}{l}\text { Proses } \\
\text { Bisnis }\end{array}$ & Sub Proses & Kode & Kejadian Risiko (Risk Event) & $S i$ \\
\hline \multirow[t]{6}{*}{ Plan } & \multirow[t]{2}{*}{$\begin{array}{l}\text { Perancangan kapasitas } \\
\text { produksi/forecasting }\end{array}$} & E1 & $\begin{array}{l}\text { Ketidakakuratan hasil forecast } \\
\text { dibandingkan dengan permintaan produk }\end{array}$ & 4 \\
\hline & & E2 & $\begin{array}{l}\text { Ketersediaan barang jadi (finish good) } \\
\text { melewati musim tanam }\end{array}$ & 4 \\
\hline & Pengendalian bahan baku & E3 & $\begin{array}{l}\text { Kesenjangan ketersediaan bahan baku } \\
\text { dengan rancangan }\end{array}$ & 3 \\
\hline & $\begin{array}{l}\text { Penyesuaian dengan } \\
\text { perencanaan biaya }\end{array}$ & $\mathrm{E} 4$ & $\begin{array}{l}\text { Ketidaksesuaian rantai pasok dengan } \\
\text { anggaran biaya }\end{array}$ & 4 \\
\hline & \multirow[t]{2}{*}{ Kondisi sempurna } & E5 & $\begin{array}{l}\text { Produk jadi yang dihasilkan tidak } \\
\text { memenuhi standar }\end{array}$ & 8 \\
\hline & & E6 & Target produksi tidak tercapai & 3 \\
\hline \multirow[t]{9}{*}{ Source } & \multirow[t]{6}{*}{$\begin{array}{l}\text { Penerimaan pengiriman } \\
\text { bahan baku }\end{array}$} & E7 & $\begin{array}{l}\text { Waktu yang lama dan proses yang panjang } \\
\text { dalam pengiriman bahan aktif }\end{array}$ & 3 \\
\hline & & E8 & $\begin{array}{l}\text { Keterlambatan penerimaan bahan baku dari } \\
\text { pemasok }\end{array}$ & 3 \\
\hline & & E9 & $\begin{array}{l}\text { Bahan baku tidak memenuhi rancangan } \\
\text { kapasitas }\end{array}$ & 4 \\
\hline & & E10 & $\begin{array}{l}\text { Bahan baku yang diterima tidak sesuai } \\
\text { spesifikasi }\end{array}$ & 8 \\
\hline & & E11 & $\begin{array}{l}\text { Mutu atau kualitas pasokan/bahan baku } \\
\text { rendah }\end{array}$ & 4 \\
\hline & & E12 & Perubahan kualitas bahan baku & 4 \\
\hline & \multirow[t]{3}{*}{$\begin{array}{l}\text { Pemilihan dan evaluasi } \\
\text { pemasok }\end{array}$} & E13 & $\begin{array}{l}\text { Tidak adanya pemasok cadangan untuk } \\
\text { item bahan baku tertentu }\end{array}$ & 4 \\
\hline & & E14 & $\begin{array}{l}\text { Ketidaksesuaian bahan baku yang dikirim } \\
\text { pemasok }\end{array}$ & 6 \\
\hline & & E15 & $\begin{array}{l}\text { Pemasok tidak menerima adanya } \\
\text { pengembalian barang }\end{array}$ & 6 \\
\hline \multirow[t]{16}{*}{ Make } & \multirow[t]{8}{*}{ Pengendalian produksi } & E16 & $\begin{array}{l}\text { Hasil pengujian bahan baku material tidak } \\
\text { sesuai standar }\end{array}$ & 4 \\
\hline & & E17 & $\begin{array}{l}\text { Bahan baku/material rusak sehingga tidak } \\
\text { dapat digunakan }\end{array}$ & 5 \\
\hline & & E18 & $\begin{array}{l}\text { Jumlah bahan baku/material tidak sesuai } \\
\text { (kurang) }\end{array}$ & 3 \\
\hline & & E19 & $\begin{array}{l}\text { Keterlambatan pelaksanaan proses } \\
\text { produksi }\end{array}$ & 4 \\
\hline & & E20 & Kerusakan atau kegagalan mesin & 7 \\
\hline & & $\mathrm{E} 21$ & Kekurangan jumlah tenaga kerja & 4 \\
\hline & & E22 & Hasil produksi tidak sempurna & 4 \\
\hline & & $\mathrm{E} 23$ & Ketidakakuratan jumlah stok barang jadi & 4 \\
\hline & \multirow{3}{*}{$\begin{array}{l}\text { Penjadwalan kegiatan } \\
\text { produksi }\end{array}$} & E24 & Keterlambatan jadwal kegiatan produksi & 4 \\
\hline & & $\mathrm{E} 25$ & $\begin{array}{l}\text { Terhambatnya kegiatan produksi akibat } \\
\text { kerusakan mekanis }\end{array}$ & 7 \\
\hline & & E26 & Proses produksi tidak efisien & 4 \\
\hline & \multirow[t]{2}{*}{$\begin{array}{l}\text { Pengecekan kualitas } \\
\text { produk }\end{array}$} & $\mathrm{E} 27$ & $\begin{array}{l}\text { Hasil inspeksi terhadap produk hasil tidak } \\
\text { sesuai standar }\end{array}$ & 4 \\
\hline & & E28 & Kerusakan atau reject pada produk hasil & 4 \\
\hline & \multirow[t]{3}{*}{ Kegiatan produksi } & E29 & Terhentinya kegiatan produksi & 9 \\
\hline & & E30 & Permintaan produk tidak mampu dipenuhi & 4 \\
\hline & & E31 & $\begin{array}{l}\text { Limbah yang dihasilkan dalam jumlah } \\
\text { besar }\end{array}$ & 4 \\
\hline \multirow[t]{5}{*}{ Deliver } & \multirow{5}{*}{$\begin{array}{l}\text { Kegiatan pengiriman } \\
\text { produk }\end{array}$} & E32 & Kekurangan kapasitas pengiriman produk & 2 \\
\hline & & E33 & $\begin{array}{l}\text { Kekurangan stok produk jadi di gudang } \\
\text { ataupun pusat distribusi }\end{array}$ & 3 \\
\hline & & E34 & $\begin{array}{l}\text { Keterlambatan pengiriman produk sampai } \\
\text { di penerima }\end{array}$ & 4 \\
\hline & & E35 & Kerusakan produk selama transportasi & 4 \\
\hline & & E36 & Kerusakan armada ekspedisi & 4 \\
\hline \multirow[t]{4}{*}{ Return } & \multirow{4}{*}{ Pengembalian produk } & E37 & Stabilitas produksi terganggu & 2 \\
\hline & & E38 & Biaya pengolahan ulang produk & 2 \\
\hline & & E39 & Penjadwalan ulang pengiriman produk & 2 \\
\hline & & $\mathrm{E} 40$ & $\begin{array}{l}\text { Kesalahan analisis penentuan keluhan } \\
\text { pelanggan }\end{array}$ & 3 \\
\hline
\end{tabular}


Tabel 8. Frekuensi kemungkinan terjadinya sumber risiko

\begin{tabular}{clc}
\hline Code & \multicolumn{1}{c}{ Risk Agent } & Oi \\
\hline A1 & Kesalahan perhitungan perancangan produksi/forecasting & 6 \\
A2 & Adanya permintaan dadakan dari pelanggan & 4 \\
A3 & Ketersediaan bahan baku tidak dapat memenuhi kapasitas produksi & 6 \\
A4 & Bahan baku tidak memenuhi standar/spesifikasi & 4 \\
A5 & Para tenaga kerja kurang berkompetensi & 5 \\
A6 & Adanya gangguan teknis dalam proses produksi & 8 \\
A7 & Target produksi yang cukup tinggi & 3 \\
A8 & Terjadinya kerusakan pada alat dan mesin produksi & 8 \\
A9 & Kurangnya pemeliharaan pada alat dan mesin produksi & 6 \\
A10 & Adanya kelalaian yang dilakukan oleh para tenaga kerja & 4 \\
A11 & Pengabaian prosedur kerja oleh karyawan & 5 \\
A12 & Pemberhentian proses produksi & 9 \\
A13 & Jangkauan pemasok bahan aktif dari luar negeri & 2 \\
A14 & Penumpukan bahan baku yang terlalu lama & 4 \\
A15 & Terjadinya kerusakan bahan baku selama proses pengiriman & 2 \\
A16 & Kebergantungan terhadap pemasok bahan baku tertentu & 5 \\
A17 & Ketersediaan jumlah tenaga kerja & 3 \\
A18 & Adanya faktor efisiensi proses & 1 \\
A19 & Terdapat faktor keterandalan dari peralatan dan mesin proses produksi & 2 \\
A20 & Keterbatasan stok produk jadi di gudang/pusat distribusi & 4 \\
A21 & Adanya keterbatasan dari armada transportasi & 4 \\
A22 & Keadaan lingkungan & 2 \\
A23 & Penumpukan stok produk jadi di gudang & 2 \\
A24 & Produk jadi tidak memenuhi standar/spesifikasi & 6 \\
\hline
\end{tabular}

Tabel 9. Prioritas nilai ARP untuk sumber risiko (risk agent)

\begin{tabular}{cclc}
\hline Rank & Code & & \multicolumn{1}{c}{ Risk Agent } \\
\hline 1 & A8 & Terjadinya kerusakan pada alat dan mesin produksi & 3.560 \\
2 & A12 & Pemberhentian proses produksi & 2.763 \\
3 & A6 & Adanya gangguan teknis dalam proses produksi & 1.848 \\
4 & A4 & Bahan baku tidak memenuhi standar/spesifikasi & 1.632 \\
5 & A5 & Para tenaga kerja kurang berkompetensi & 1.515 \\
6 & A24 & Produk jadi tidak memenuhi standar/spesifikasi & 1.410 \\
7 & A9 & Kurangnya pemeliharaan pada alat dan mesin produksi & 1.284 \\
8 & A3 & Ketersediaan bahan baku tidak dapat memenuhi kapasitas produksi & 1.278 \\
9 & A10 & Adanya kelalaian yang dilakukan oleh para tenaga kerja & 1.124 \\
10 & A11 & Pengabaian prosedur kerja oleh karyawan & 1.075 \\
11 & A1 & Kesalahan perhitungan perancangan produksi/forecasting & 1.068 \\
12 & A16 & Kebergantungan terhadap pemasok bahan baku tertentu & 560 \\
13 & A2 & Adanya permintaan dadakan dari pelanggan & 532 \\
14 & A17 & Ketersediaan jumlah tenaga kerja & 351 \\
15 & A14 & Penumpukan bahan baku yang terlalu lama & 324 \\
16 & A15 & Terjadinya kerusakan bahan baku selama proses pengiriman & 296 \\
17 & A19 & Terdapat faktor keterandalan dari peralatan dan mesin proses produksi & 288 \\
18 & A21 & Adanya keterbatasan dari armada transportasi & 276 \\
19 & A20 & Keterbatasan stok produk jadi di gudang/pusat distribusi & 188 \\
20 & A7 & Target produksi yang cukup tinggi & 135 \\
21 & A13 & Jangkauan pemasok bahan aktif dari luar negeri & 106 \\
22 & A22 & Keadaan lingkungan & 88 \\
23 & A18 & Adanya faktor efisiensi proses & 83 \\
24 & A23 & Penumpukan stok produk jadi di gudang & 24 \\
\hline
\end{tabular}




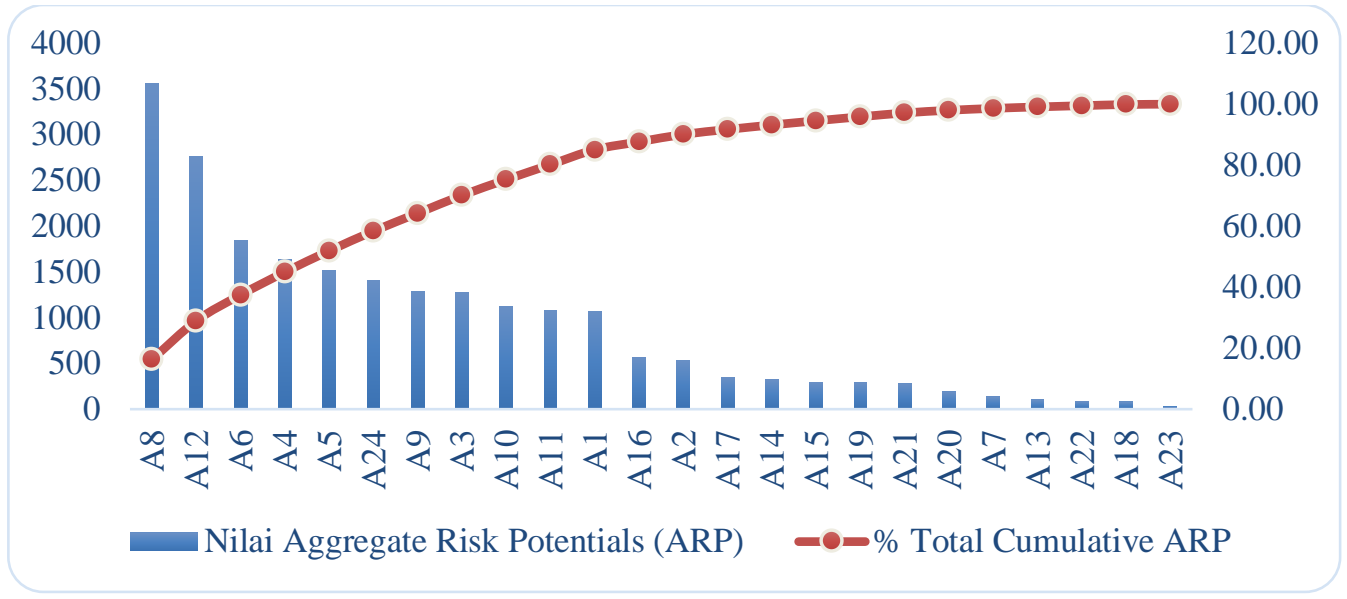

Gambar 6. Diagram pareto dari ARP untuk prioritas sumber risiko

Tahap terakhir adalah melakukan klasifikasi sumber risiko menjadi 3 (tiga) bagian, yaitu klasifikasi A (sumber risiko tingkat tinggi, 50\% dari keseluruhan sumber risiko), klasifikasi B (sumber risiko tingkat sedang, 30\% dari keseluruhan sumber risiko), dan klasifikasi $\mathrm{C}$ (sumber risiko tingkat rendah, 20\% dari keseluruhan sumber risiko) (Ulfah, 2016). Berdasarkan hasil klasifikasi sumber risiko, maka terpilih 10 (sepuluh) sumber risiko yang akan diprioritaskan untuk segera diselesaikan. Sumber risiko yang terpilih tersebut adalah 1) terjadinya kerusakan pada alat dan mesin produksi $(\mathrm{ARP}=3.560)$, 2) pemberhentian proses produksi $(\mathrm{ARP}=2.763), 3)$ adanya gangguan teknis dalam proses produksi $(\mathrm{ARP}=1.848)$, 4) bahan baku tidak memenuhi standar/spesifikasi $(\mathrm{ARP}=1.632), 5)$ para tenaga kerja kurang berkompetensi $(\mathrm{ARP}=1.515), 6)$ produk jadi tidak memenuhi standar/spesifikasi $(\mathrm{ARP}=1.410), 7)$ kurangnya pemeliharaan pada alat dan mesin produksi ( $\mathrm{ARP}=1.284), 8)$ ketersediaan bahan baku tidak dapat memenuhi kapasitas produksi $(\mathrm{ARP}=1.278), 9)$ adanya kelalaian yang dilakukan oleh para tenaga kerja $(\mathrm{ARP}=1.124)$, dan 10) pengabaian prosedur kerja oleh karyawan $(\mathrm{ARP}=1.075)$. Selain itu, berdasarkan hasil klasifikasi sumber risiko menunjukkan bahwa $51,90 \%$ sumber risiko masuk kedalam klasifikasi A, 28,30\% sumber risiko masuk kedalam klasifikasi B, dan 19,80\% sumber risiko masuk kedalam klasifikasi C seperti disajikan pada Tabel 10, sedangkan pemodelan House of Risk 1 dapat dilihat pada Gambar 7.

\section{Alternatif Mitigasi Risiko}

Dalam rangka mengurangi sumber risiko dalam rantai pasok pestisida maka diperlukan alternatif mitigasi risiko terhadap 10 (sepuluh) prioritas sumber risiko hasil analisis HOR 1. Untuk mengurangi sumber risiko terjadinya kerusakan pada alat dan mesin produksi, maka diperlukan aksi mitigasi berupa penjadwalan kegiatan preventive dan predictive maintenance secara rutin agar kondisi peralatan dan mesin produksi selalu terjaga dan tidak mengganggu proses produksi. Pemberhentian proses produksi perlu ditangani dengan peningkatan koordinasi dalam manajemen perusahaan dan bagian terkait lainnya agar semua kegiatan dapat berjalan sinergi dan seimbang. Gangguan teknis dalam proses produksi perlu diantisipasi dengan mempersiapkan alat dan mesin cadangan untuk menghindari kerusakan, sehingga proses produksi dapat terus berjalan dan menjamin ketersediaan produk.

Bahan baku yang tidak memenuhi standar dapat diberikan tindakan penanganan dengan memperketat proses quality control internal serta evaluasi kinerja pemasok untuk langkah tindak lanjut kerjasama. Tenaga kerja yang kurang berkompetensi perlu ditangani dengan melakukan standarisasi dan memperketat proses penerimaan pegawai serta pemberian pelatihan secara berkala, sehingga dapat menyeleksi tenaga kerja terbaik dan meningkatkan kapasitas tenaga kerja. Produk jadi tidak memenuhi standar/spesifikasi perlu ditangani dengan melakukan tindakan evaluasi dan memperketat seluruh rangkaian proses sistem produksi agar berjalan secara efektif dan efisien.

Kurangnya pemeliharaan pada alat dan mesin produksi dapat menyebabkan hambatan dalam proses produksi sehingga perlu dilakukan perbaikan rancangan produksi dan evaluasi prosedur pemeliharaan. Ketersediaan bahan baku tidak dapat memenuhi kapasitas produksi perlu ditangani dengan melakukan review sistem material requirements planning (MRP) dan buffer stock dalam menjamin kelancaran proses produksi. Terjadinya kelalaian tenaga kerja dapat menghambat seluruh proses dalam rantai pasok, sehingga diperlukan tindakan penanganan berupa pengawasan yang ketat dan penerapan standar operasional prosedur (SOP) tenaga kerja agar seluruh kegiatan dapat terkendali dengan baik, sedangkan pengabaian prosedur kerja oleh karyawan dapat ditangani dengan melakukan audit mutu internal dan pengukuran kerja tenaga kerja, sehingga dapat diketahui prestasi dan kekurangan yang perlu diperbaiki dimasa yang akan datang. 


\section{Implikasi Manajerial}

Pengukuran kinerja dapat dilakukan secara rutin dan terjadwal guna menjaga efisiensi perusahaan serta menjalankan fungsi evaluasi pada proses bisnis dalam rantai pasok. Pengukuran kinerja dengan model SCOR dapat mengontrol setiap dimensi didalam rantai pasok, sehingga permasalahan dan kendala yang terjadi dapat dengan mudah terdeteksi. Dengan adanya pengukuran kinerja maka manajemen dapat merencanakan perbaikan dan peningkatan kinerja rantai pasok melalui berbagai tindakan koreksi sehingga dapat meningkatkan daya saing perusahaan. Dari hasil pengukuran kinerja rantai pasok pestisida, diketahui bahwa matrik siklus pemenuhan pesanan, matrik fleksibilitas rantai pasok atas dan matrik penyesuaian rantai pasok atas masih memiliki nilai yang rendah dibandingkan dengan target yang akan dicapai perusahaan. Oleh karena itu, rencana perbaikan yang perlu dilakukan adalah perbaikan rancangan produksi, evaluasi kinerja pemasok, serta peningkatan koordinasi dan kerja sama dengan berbagai pihak yang terlibat dalam manajemen rantai pasok perusahaan sehingga dapat meningkatkan kinerja rantai pasok pestisida. Oleh karena itu, dengan dilakukannya analisis risiko pada rantai pasok pestisida, maka diharapkan berbagai sumber risiko yang ada dapat segera dikurangi ataupun dihilangkan dengan menerapkan alternatif mitigasi risiko.
Hasil analisis risiko rantai pasok pestisida dapat mengidentifikasi prioritas sumber risiko potensial yang terjadi didalam rantai pasok, yaitu terjadinya kerusakan pada alat dan mesin produksi, pemberhentian proses produksi, adanya gangguan teknis dalam proses produksi, bahan baku tidak memenuhi standar/spesifikasi, dan para tenaga kerja kurang berkompetensi yang dapat menjadi fokus untuk perbaikan kinerja dari sisi manajerial perusahaan. Alternatif mitigasi risiko diharapkan dapat diimplementasikan perusahaan untuk mengurangi sumber risiko dalam rantai pasok pestisida.

\section{KESIMPULAN DAN SARAN}

\section{Kesimpulan}

Mekanisme rantai pasok pestisida diawali dengan tahapan pengadaan bahan baku, proses pengolahan/produksi, pengemasan, penyimpanan di gudang, dan distribusi sampai ke konsumen akhir. Hasil pengukuran kinerja rantai pasok pestisida menunjukkan masih terdapat hal-hal yang perlu diperbaiki dan ditingkatkan, yaitu dengan perbaikan pada siklus pemenuhan pesanan, fleksibilitas rantai pasok atas dan penyesuaian rantai pasok atas yang sampai saat ini masih memiliki nilai yang rendah dibandingkan dengan target perusahaan.

Tabel 10. Klasifikasi sumber risiko

\begin{tabular}{cccccc}
\hline Rank & Risk Agent & Nilai ARP & $\begin{array}{c}\text { Total Cum } \\
\text { ARP }\end{array}$ & $\begin{array}{c}\text { \% Total Cum } \\
\text { ARP }\end{array}$ & $\begin{array}{c}\text { Klasifikasi ABC } \\
\text { Risiko }\end{array}$ \\
\hline 1 & A8 & 3.560 & 3.560 & 16,32 & \\
2 & A12 & 2.763 & 6.323 & 28,99 & Klasifikasi A \\
3 & A6 & 1.848 & 8.171 & 37,47 & (risiko tinggi) \\
4 & A4 & 1.632 & 9.803 & 44,95 & \\
5 & A5 & 1.515 & 11.318 & 51,90 & Klasifikasi B \\
\hline 6 & A24 & 1.410 & 12.728 & 58,36 & (risiko sedang) \\
7 & A9 & 1.284 & 14.012 & 64,25 & \\
8 & A3 & 1.278 & 15.290 & 70,11 & \\
9 & A10 & 1.124 & 16.414 & 75,27 & \\
10 & A11 & 1.075 & 17.489 & 80,20 & \\
\hline 11 & A1 & 1.068 & 18.557 & 85,09 & \\
12 & A16 & 560 & 19.117 & 87,66 & \\
13 & A2 & 532 & 19.649 & 90,10 & \\
14 & A17 & 351 & 20.000 & 91,71 & \\
15 & A14 & 324 & 20.324 & 93,20 & \\
16 & A15 & 296 & 20.620 & 94,55 & \\
17 & A19 & 288 & 20.908 & 95,87 & \\
18 & A21 & 276 & 21.184 & 97,14 & \\
19 & A20 & 188 & 21.372 & 98,00 & \\
20 & A7 & 135 & 21.507 & 98,62 & \\
21 & A13 & 106 & 21.613 & 99,11 & \\
22 & A22 & 88 & 21.701 & 99,51 & \\
23 & A18 & 83 & 21.784 & 99.89 & \\
24 & A23 & 24 & 21.808 & 100,00 & \\
\hline
\end{tabular}




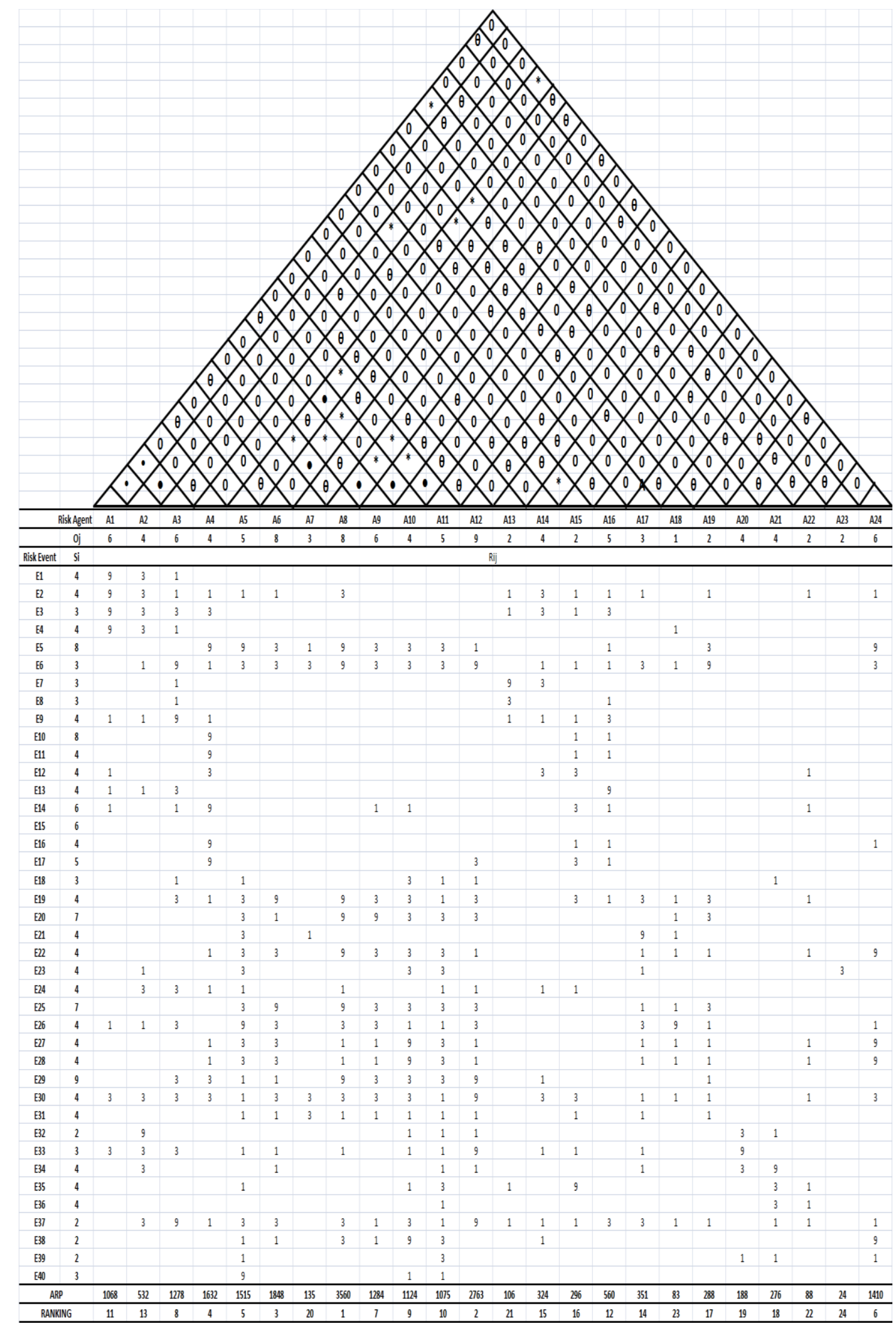

Gambar 7. Pemodelan House of Risk 1 
Kinerja rantai pasok pestisida berada pada kriteria buruk (unacceptable) yang menyebabkan hilangnya berbagai kesempatan (lost opportunity) karena tidak dapat terpenuhinya target perusahaan yang berdampak pada kehilangan keuntungan (profit loss). Belum optimalnya kinerja rantai pasok disebabkan adanya risiko yang terjadi dalam rantai pasok, sehingga dari hasil analisis dan evaluasi risiko diketahui beberapa sumber risiko potensial yang terjadi, di antaranya kerusakan pada alat dan mesin produksi, pemberhentian proses produksi, adanya gangguan teknis dalam proses produksi, bahan baku tidak memenuhi standar/spesifikasi, dan para tenaga kerja kurang berkompetensi yang perlu segera memperoleh aksi mitigasi agar dapat mencapai kinerja rantai pasok pestisida yang kokoh.

\section{Saran}

Terdapat beberapa hal yang perlu menjadi perhatian dan ditindaklanjuti dari hasil penelitian ini baik bagi perusahaan maupun untuk penelitian selanjutnya, yaitu alternatif tindakan untuk peningkatan kinerja rantai pasok pestisida berupa perbaikan rancangan produksi, evaluasi kinerja pemasok, serta peningkatan koordinasi dan kerja sama dengan berbagai pihak yang terlibat dalam manajemen rantai pasok perusahaan dapat diimplementasikan oleh perusahaan. Hasil identifikasi, analisis dan evaluasi risiko diharapkan dapat mengurangi prioritas sumber risiko yang menyebabkan berbagai kejadian risiko didalam rantai pasok pestisida. Untuk penelitian selanjutnya diharapkan dapat dilakukan analisis penanganan atau mitigasi risiko dengan metode HOR 2 dalam rangka mengurangi sumber risiko rantai pasok, serta penentuan strategi dalam pengelolaan rantai pasok pestisida yang kokoh dengan menggunakan metode Analytical Networking Process (ANP). Selain itu, model pengukuran kinerja rantai pasok ini dapat diterapkan pada berbagai industri atau perusahaan dengan menyesuaikan matrik pengukuran kinerjanya.

\section{DAFTAR PUSTAKA}

Abror N, Marimin, dan Indah Y. 2011. Seleksi dan evaluasi pemasok pada rantai pasokan kertas. Jurnal Teknologi Industri Pertanian. 21 (3):194-206.

[BPS] Badan Pusat Statistika. 2018. Jakarta (ID).

Craighead CW, Blackhurst J, Rungtusanatham MJ, Handfield RB. 2007. The severity of supply chain disruptions : Design characteristics and mitigation capabilities. Decision Sciences. 38(1):131-156.

Georgise FB, Klaus-Dieter T, dan Marcus S. 2013. Implementing the SCOR model best practices for supply chain improvement in developing countries. International Journal of $u^{-}$and $e^{-}$Service, Science and Technology. 6(4).
Geraldin LH, Pujawan IN, dan Dewi DS. 2007. Manajemen risiko dan aksi mitigasi untuk menciptakan rantai pasok yang robust. Jurnal Teknologi dan Rekayasa Teknik Sipil "TORSI". 3:53-64.

Goh M, Lim JYS, dan Meng F. 2007. A stochastic model for risk management in global supply chain networks. European Journal Operational Research. 182:164-173.

Hallikas J, Karvonen I, Pulkkinen U, Virolainen V-M dan Tuominen M. 2004. Risk management processes in supplier networks. International Journal Production Economics. 90(1):47-58.

Hendricks K dan Singhal V. 2003. The effect of supply chain glitches on shareholder wealth. Journal of Operation Management.

Hora SC, Fransen BR, Hawkins N, Susel I. 2013. Median Aggregation Distribution Functions. California (US): Published Articles \& Papers.

Jamehshooran BG, Shaharoun M, dan Haron HN. 2015. Assessing supply chain performance through applying the SCOR model. International Journal Supply Chain Management. 4(1):1-11.

Monczka R, Trent RJ, dan Handfield RB. 2011. Purchasing and Supply Chain Management 5th Edition. Ohio, South-Western (US) : Cengage Learning.

Norrman A dan Jannson U. 2004. Ericsson's proactive supply chain risk management approach after a serious sub-supplier accident. International Journal of Physical Distribution and Logistics Management. 34(5):434-456.

Pujawan IN. 2005. Supply Chain Management. Surabaya (ID) : Guna Widya.

Pujawan IN dan Geraldine LH. 2009. House of risk : A model for proactive supply chain risk management. Business Process Management Journal. 15(6):953-967.

Septiani W, Marimin, Herdiyeni Y, Haditjaroko L. 2016. Risk depedency chain model of dairy agro-industry supply chain using fuzzy logic approach. Supply Chain Forum: An International Journal. 17(4): 218-230.

Sinha PR, Whitman LE, dan Malzahn D. 2004. Methodology to mitigate supplier risk in an aerospace supply chain. Supply Chain Management : An International Journal. 9(2):154-168.

Sodhi MS dan Tang CS. 2012. Managing Supply Chain Risk. International Series in Operations Research and Management Science. Volume 172. New York (US) : Springer Science Business Media, LLC. Ebook

Tang CS. 2006. Robust strategies for mitigating supply chain disruptions. International 
Journal Logistics : Research and Applications.

$9(1): 33-$

45.doi:10.1080/13675560500405584.

Ulfah M. 2016. Rancang bangun model manajemen risiko rantai pasok gula rafinasi [disertasi]. Bogor (ID) : Institut Pertanian Bogor.
Van der Vorst JGAJ. 2006. Performance Measurement in Agri-food Supply Chain Networks : An Overview. In : Quantifying the Agri-food Supply Chain 13-24. Wageningen (NL) : Logistics and Operations Research Grou 